\title{
Rewriting the history of science
}

SIR - In his review of Mary Midgley's book Science as Salvation (Nature 357, $550 ; 1992)$, Stuart Sutherland overlooks Midgley's attempts to rewrite history. According to her, "Descartes's distinctive move, which made room for Galileo and modern physics, was not his scepticism, but his finding a way out of that scepticism by a radical act of trust in scientific reason" (p.124). Not so. Galileo (1564-1642) was 32 years senior to Descartes (1596-1650). By the time Descartes was 20 , Galileo was already under investigation by the Inquisition for his scientific reasoning ${ }^{1}$.

Moreover, Midgley writes that "mechanistic scientists who fill the rest of our pantheon rejected Kepler's view fiercely as superstitious. In particular Galileo, who might have been expected to welcome Kepler's support for the Copernican system, simply ignored it" (pp 82-83). Kepler in fact gave two copies of his first book to Paul Hamberger to leave with astronomers in Italy. Both were given to Galileo, who on 4 August 1597 wrote in haste to thank Kepler, explaining that he had had the book only a matter of hours, without time to study it, although the return of Hamberger to Germany made it imperative for him to write at once. Indeed, Galileo rejoiced to find that Kepler supported Copernicus, whose view Galileo had now held for a number of years ${ }^{2}$.

Midgley fails to appreciate that the reason why Galileo did not talk openly about new ideas in favour of Copernicanism was that he was intimidated by the Church's condemnation of Copernicus. Kepler's and Copernicus's works were on the Jesuit Index; they could not legally circulate within the ambit of the Church. Galileo had already in 1616 had a friendly 'fireside chat' with Cardinal Bellarmino, and was effectively silenced (he was forced by the Inquisition to recant his views and sentenced to life imprisonment in 1633). By contrast, Kepler was a Protestant in Protestant Germany and free to speak, while Descartes, although having the protection of the French Court, migrated first to Holland and then to Protestant Sweden.

Alex Mllne

39 Sanderson Road,

Newcastle upon Tyne NE2 2DR, UK

1. Redondi, P. Galileo: Heretic (Lane, London, 1988)

2. Drake, S. Galileo at Work: His Scientific Biography (University of Chicago Press, 1978).

SIR - I understand Steven Rose's annoyance (Nature 359, 10; 1992) at Stuart Sutherland's casually terming J. D. Bernal and J. B. S. Haldane as "crackpots". But I am annoyed with
Rose for quoting Sutherland flagrantly out of context.

Sutherland wrote that Bernal and Haldane "became crackpots when they left their laboratories" to engage in "armchair utterances". Their grasp of complex political and social problems was often (not always) more tenuous than their grip on the physical and life sciences, a manifestation many other gifted scientists have displayed from time to time. What Sutherland is in fact saying is that, brilliant as Bernal and Haldane were in their fields of expertise, once out of them they were capable of writing just as stupidly as the rest of us, thus allowing individuals such as Mary Midgley to pounce on their sillier remarks and use these as sticks with which to beat science in her (and others') crusade against science's "soullessness" and "amorality".

If Rose then (rightly) claims that Midgley et al. are being less than honest with their selected quotations, he should bear this in mind to his own advantage. Ralph Estling

The Old Parsonage,

Dowlish Wake,

IIminster, Somerset

TA19 ONY, UK

\section{Brown's observations confirmed}

SIR - The recent claims that Robert Brown could not have observed brownian movement can now be laid to rest. I have demonstrated videomicrographs of the phenomenon, seen through Brown's own microscope, at Inter Micro (Chicago, Illinois, July 1992). The recordings reveal the clarity with which Brown observed the phenomenon that now bears his name.

Your correspondent Cadée ${ }^{1}$ is taken to task by Deutsch ${ }^{2}$ for a slight misquotation in his letter. Deutsch com-

\section{Four frame enlargements} from video imaging of brownian movement. The test specimen is suspended globules in milk, and the scale bar represents $10 \mu \mathrm{m}$. Frame separation 0.5 seconds, and the high-power lens from Brown's microscope is calibrated at a magnification of $\times 170$. It resolves particulates of $1.3 \mu \mathrm{m}$ diameter. The microscope is in the collection of the Linnean Society.

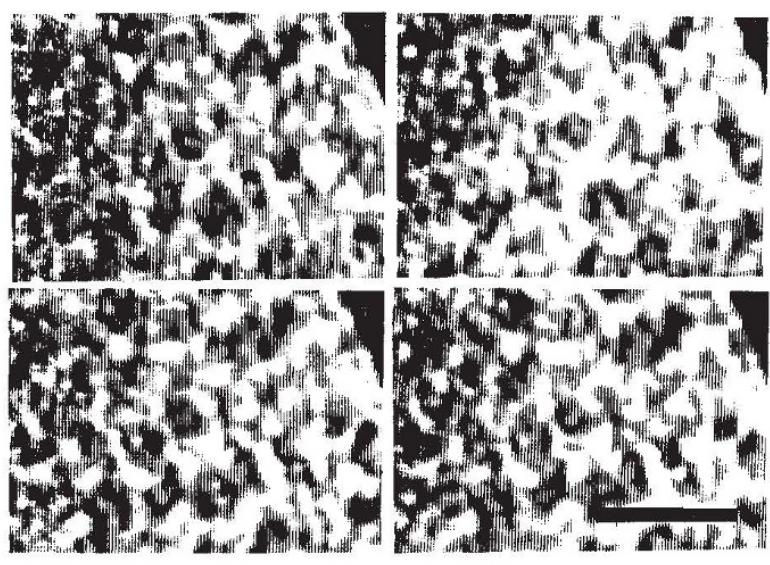

plains that he is wrongly cited as having said that Brown's particles were "too large... e.g. pollen", and that he actually said they were "too light". Deutsch has published his belief that Brown claimed to observe the phenomenon in the movement of pollen grains, and this common misconception is incorrect.

As Brown makes perfectly plain, his observations were of the intracellular granules within the pollen cells, and not of the entire grains themselves ${ }^{3}$. Furthermore, Brown took great pains to avoid external perturbations and was clearly aware of the problems that might be caused by currents induced by such factors. Each of Deutsch's objections can be faulted by a careful consultation of
Brown's privately printed account ${ }^{4}$.

The authority now cited by Deutsch ${ }^{5}$ produced an interesting account, although it perpetrated the widespread belief that the simple microscope was not capable of generating images of sufficient resolution. Perrin writes that the phenomenon was described "very shortly after the discovery of the achromatic objective". This comment is misleading.

As Brown makes clear, his observations were made using the simple (single lens) microscope. He had brief recourse to an early achromatic compound system, but soon returned to the single lens ${ }^{3}$. The "pseudo-brownian movement" postulated by Deutsch is certainly not recognized by Perrin, or by other major workers in the field. I am aware of no evidence that it exists.

\section{Brian J. Ford}

Rothay House, Mayfield Road,

Eastrea, Cambridge PE7 2AY, UK.

\footnotetext{
1. Cadée, G. C. Nature, 354, 180 (1991). 2. Deutsch, D. H. Nature, 357, 354 (1992).

3. Brown, R. A brief account of microscopical observations made in the months of June, July and August 1827 on the particles contained in the pollen of plants and Additional remakrs on active molecules (London, 1828). 4. Ford, J. The Microscope 39 (3 \& 4), 161-173 (1991).

5. Perrin, J. Brownian Movement and Molecular Reality (London, 1910).
} 